\title{
Oil source and accumulation in the overthrust belt in the Ke-Bai region, Junggar Basin, west China
}

\author{
Liu Guangdi*, Gao Gang, Huang Zhilong and Yang Haifeng \\ State Key Laboratory of Petroleum Resources and Prospecting, China University of Petroleum, Beijing 102249, China \\ (C) China University of Petroleum (Beijing) and Springer-Verlag Berlin Heidelberg 2010
}

\begin{abstract}
The region around the Karamay-Baikouquan (Ke-Bai) overthrust belt is the richest in hydrocarbon accumulation in the Junggar Basin. Previous research has indicated that oil in the region came from the Fengcheng Formation in the Mahu Depression to the northeast of the region, but the oil distribution around the Mahu Depression is remarkably uneven. Large amounts of oil have been found in the Ke-Bai overthrust belt to the west of the depression and only some small oilfields have been discovered in the eastern margin of the depression. This uneven distribution revealed that the oil source of the KeBai region might not be from the Mahu Depression. The oil type distribution and the oil migration pattern revealed in this paper showed that there may be another oil source under the Karamay overthrust. Based on geochemical data, the oil was classified into two types from the sterane and terpane characteristics. Type A oil was mainly distributed in the Huwan area and blocks V and VIII of the Karamay Oilfield in the southern part of the region, while type B oil was mainly distributed in the Baikouquan Oilfield in the northern part of the region. In addition, oil migration pathways and direction were determined by the values of diasterane / regular sterane and $\mathrm{C}_{30}$ moretane / $\mathrm{C}_{30}$ hopane ratios. It is shown that the oil of Huwan area on the hanging wall of the overthrust was mainly charged along the overthrust fault surfaces and then migrated to the west, whereas the oil in blocks V and VIII on the foot wall of the overthrust came from the Mahu Depression in the east. As a result, there may be at least two hydrocarbon source kitchens in the study area. The hydrocarbons in the blocks V and VIII on the footwall of the overthrust belt and in the Baikouquan Oilfield mainly came from the Fengcheng Formation in the Mahu Depression, and the hydrocarbons in the Huwan area on the hanging wall of the overthrust belt may come from another hydrocarbon source kitchen below the overthrust. This recognition indicates that there is substantial exploration potential in the deep Carboniferous strata on the hanging wall of the overthrust belt.
\end{abstract}

Key words: Overthrust belt, oil migration, oil type, source rock, Junggar Basin

\section{Introduction}

In the $1930 \mathrm{~s}$, petroleum explorers in China discovered the famous Laojunmiao Oilfield in the piedmont fold zone of Qilianshan Mountain in the Jiuquan Basin, and hydrocarbon exploration in overthrust belts started (Zhai, 1989). Afterwards large oil and gas fields such as the Karamay Oilfield, Kela-2 Gas Field, and Dina-2 Gas Field were discovered (Qiu and Gong, 1999; Jia et al, 2002), which further promoted hydrocarbon exploration in overthrust belts. The Pineview Oilfield was discovered in the overthrust belt of the Rocky Mountains in the United States in the mid 1970s (McClay, 2004), which hence caused petroleum geologists to attach importance to the exploration potential of overthrust belts. Important discoveries were successively made in the Utah-Wyoming overthrust belt, Eastern Appalachia overthrust belt, and Southern Ouachita overthrust belt in the United

*Corresponding author. email: lgd@cup.edu.cn

Received September 15, 2009
States, thereby opening up a new hydrocarbon exploration field. AAPG (American Association of Petroleum Geologists) detailed the petroleum geology core issues on the overthrust belt such as trap forming mechanism, dominant migration pathways, and preservation mechanism in a special issue in 1997, so that overthrust belts became a focus for hydrocarbon exploration (Macqueen and Leckie, 1997).

There has long been vigorous discussion of hydrocarbon migration and accumulation in overthrust belts. Some scholars (Young et al, 1977; Alsharhan, 1985; Wu et al, 2002) thought that the oil and gas in overthrust belts should come mainly from the deep sags inside basins and migrate laterally for long distances into piedmont faulted anticline traps via complex "stepladder" transport systems consisting of sand bodies, unconformities, and faults. Also some scholars (Wilson, 1982; Ameen, 1991; Zou et al, 2005; 2007) thought that hydrocarbon resources in overthrust belts should come from effective source rocks beneath nappes and migrate vertically along faults. Other studies indicate (Zhai, 1989) that the oil and gas in overthrust belts can migrate laterally in 
the direction vertical to the nappe along the main fault zone. Complex geological environments bring great challenges to hydrocarbon exploration in overthrust belts and difficulties for the study of hydrocarbon accumulation in the area.

Under such complex geological conditions, source rock beneath nappes cannot in general be sampled directly. Therefore, it is difficult to compare oil sources directly, and geological and geochemical analysis is generally used as a main tool for the study of hydrocarbon migration. With the improvement of geochemical analysis and testing methods, a large number of biomarkers such as sterane and terpane have been introduced in the study of hydrocarbon source correlation and hydrocarbon migration (Wolff et al, 1986; Peters et al, 1990; Summons et al, 1992; Thomas et al, 1993; Horsfield et al, 1994; Dahl et al, 1995). Biomarkers were used to distinguish the biological source and depositional environment of original source materials (Summons et al, 1992; Thomas et al, 1993; Dahl et al, 1995) and to indicate hydrocarbon migration direction and distance. This has greatly improved the accuracy of hydrocarbon source correlation and has strengthened geological research. Understanding of the regional distribution of hydrocarbon properties, original hydrocarbon source materials, and hydrocarbon maturity will greatly help to deduce and analyze the hydrocarbon migration and accumulation process.

The northwestern margin of the Junggar Basin is a typical overthrust belt and is the richest in oil and gas in the basin. Previous researchers thought that the oil in the overthrust belt mainly came from lacustrine source rocks of the lower Permian Fengcheng Formation in the Mahu Depression to the northeast of the overthrust belt (Wang and Kang, 1999; Zhang et al, 2000; Zhang and Zhang, 2006). However, this viewpoint needs to be further discussed from the aspect of the petroleum distribution around the Mahu Depression. It can be seen from Fig. 1 that the hydrocarbon source center of the Mahu Depression is close to the Baikouquan, Wuerhe, and Xiazijie oilfields in the northwestern margin and is a long distance from the Karamay Oilfield where most of the

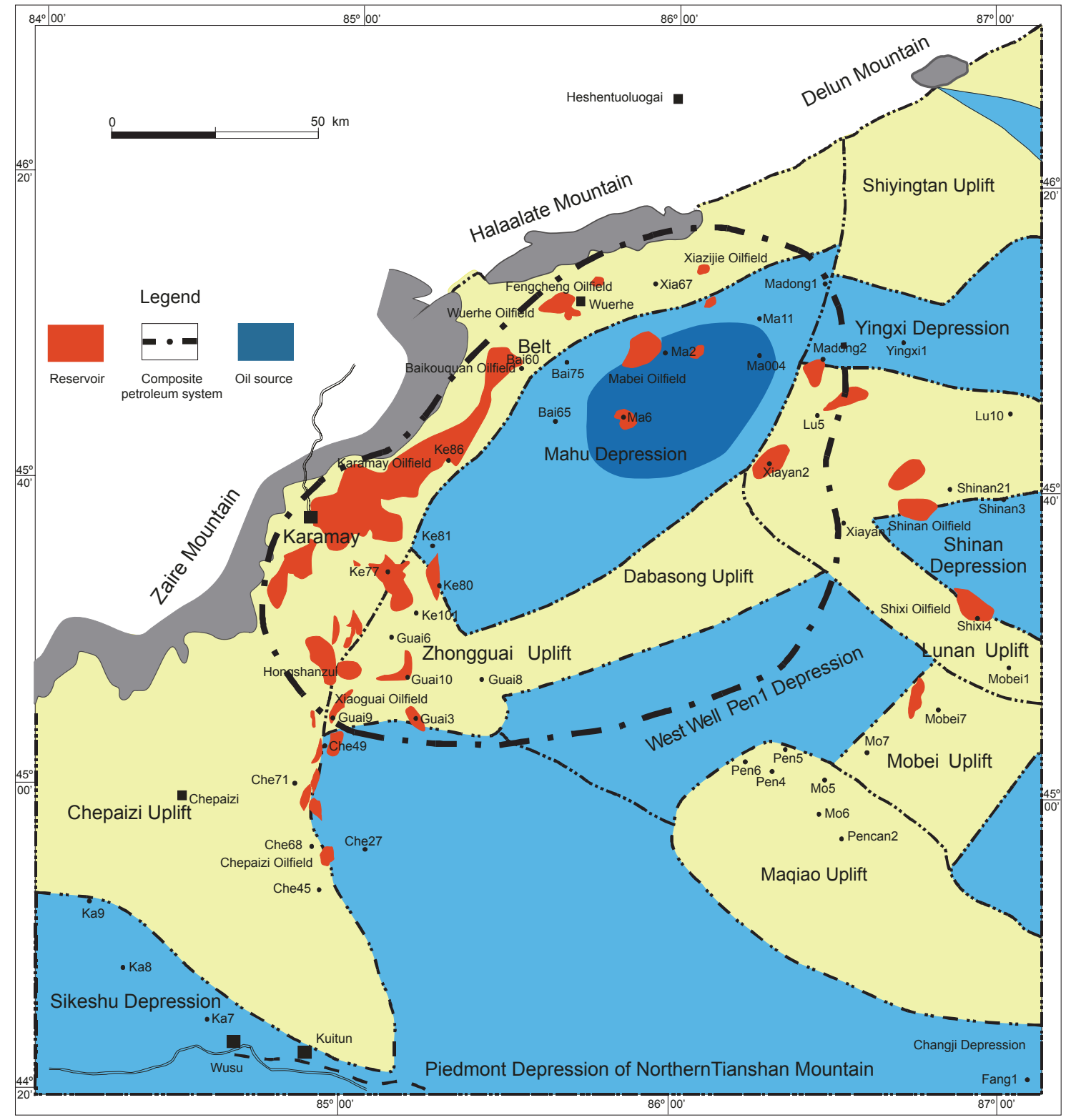

Fig. 1 Hydrocarbon distribution around the Mahu Depression (from Xinjiang Oilfield Company) 
oil in the northwestern margin accumulates. Furthermore, comparing the hydrocarbon distribution between the east and the west sides of the Mahu Depression showed that the hydrocarbon was mainly on the west side of the Mahu Depression, whereas in the slope area on the east side of the Mahu Depression it was extremely limited with only a small quantity of hydrocarbon distributed in the Xiayan and Madong areas. Such extremely unbalanced distribution of hydrocarbon on the two sides of the depression did not follow the basic rules of petroleum migration and accumulation. Admittedly, the distribution of discovered oil and gas was controlled by exploration degree, but little hydrocarbon was discovered in quite a large number of exploration wells in the Madong and Xiayan areas on the east side of the depression. The only reasonable explanation would be that the oil of the Karamay Oilfield was not from the Mahu Depression. If the oil of the Karamay Oilfield is excluded, the hydrocarbon distribution of the oilfields including Baikouquan, Wuerhe, Xiazijie, Mabei, and Madong as well as the areas including Xiayan and Madong around the hydrocarbon generation center of the Fengcheng Formation at the north end of the
Mahu Depression is uniform. None of hydrocarbon supply, transport system, trap distribution, and other geological conditions could reasonably explain the reason for the great difference in hydrocarbon resource abundance between the two sides of the depression. In this paper, the oil genetic type and migration direction are discussed based on the geochemical characteristics of oil from the Ke-Bai region in the northwestern margin of the Junggar Basin, and the possible sources and migration and accumulation model in the overthrust belt were concluded.

\section{Geological background}

The Ke-Bai region, in which the famous Karamay and Baikouquan oilfields are located, is the main part of the overthrust belt in the northwestern margin of the Junggar Basin and is adjacent to the Zaire Mountain westward and Mahu Depression eastward. The Ke-Bai region is divided into several blocks, including block I to IX, Baikouquan south block, and Baikouquan north block, totaling about $2,000 \mathrm{~km}^{2}$ in area (Fig. 2). Block I to IV are also called the Huwan area

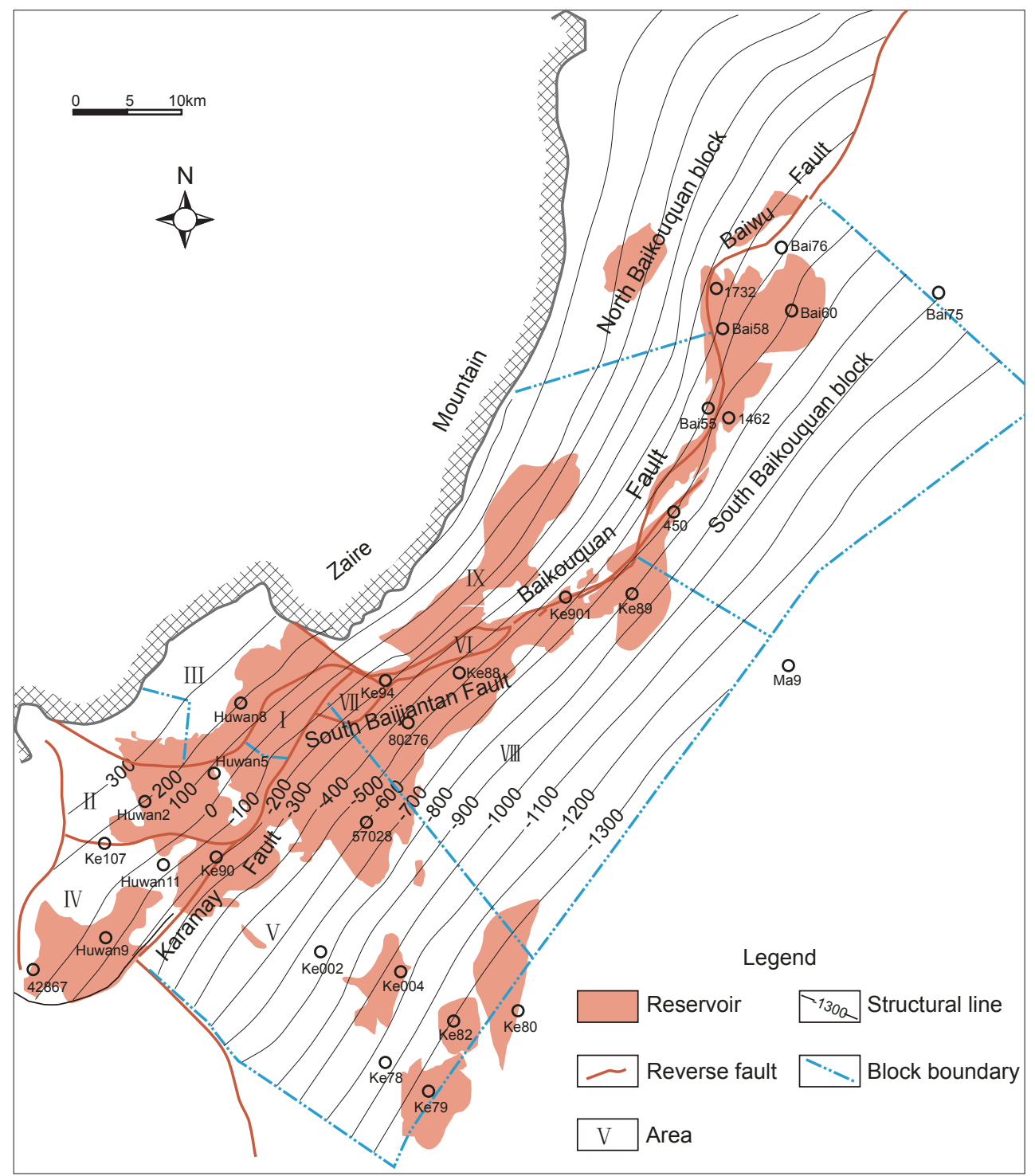

Fig. 2 Basic geologic features of the Ke-Bai region 
as a whole. The Karamay Oilfield is in the southern part of the overthrust belt and includes the Huwan area, blocks VI, VII and IX on the hanging wall of the overthrust, and blocks V and VIII on the foot wall. The Baikouquan Oilfield is located in the northern part of the overthrust belt and includes the Baikouquan north block on the hanging wall and Baikouquan south block on the foot wall. Carboniferous, Permian, Triassic, Jurassic, and Cretaceous are the main oil-bearing formations in the region. The Ke-Bai overthrust belt is a large imbricate overthrust system, and the overthrust faults are steep in the upper part and gentle in the lower part, with slippage at around $12 \mathrm{~km}$. The strata on the hanging wall are seriously eroded, and the main body is an overthrust nappe composed of Carboniferous-Triassic strata. On the nappe, there are Jurassic-Cretaceous wedged overlap sediments. On the footwall of the overthrust belt, Carboniferous-Cretaceous strata are well developed (Fig. 3). Based on the differences in structural assemblage and sedimentary characteristics, the Ke-Bai fault belt can be divided into the nappe pinch zone, faulted zone, fault front zone and slope zone. In addition, several regional unconformities were developed in the region (Zhang and Zhang, 2006; Guan et al, 2008). These faults and unconformities played an important role in hydrocarbon migration and accumulation.

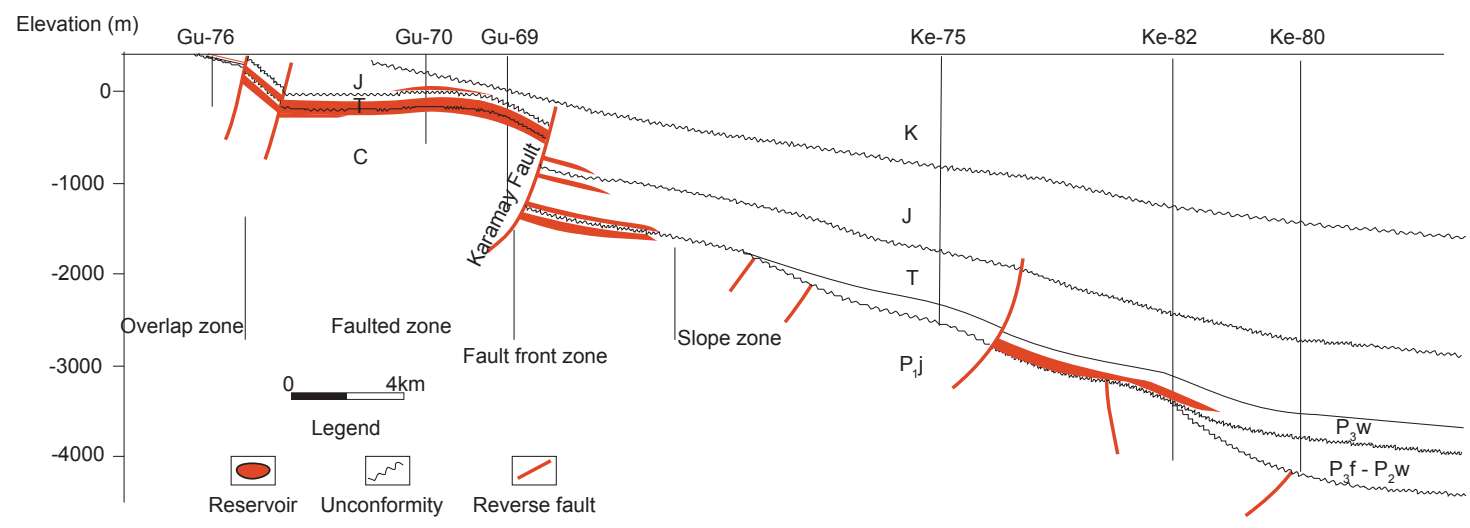

Fig. 3 Cross section through wells Gu76-Ke80 in the Ke-Bai region

\section{Oil distribution and classification}

\subsection{Oil distribution}

The Ke-Bai region is the richest in oil in the Junggar Basin, but the oil distribution within the region is very uneven both laterally and vertically. Oil reservoirs are mainly distributed near the Ke-Bai overthrust belt and on its hanging wall (Fig. 2). From the viewpoint of development blocks, oil reservoirs are distributed mainly in the Huwan area and the fault front zone in the blocks V and VIII.

In the stratigraphic section, oil is discovered in the Carboniferous, Permian, Triassic, and Jurassic strata, but the oil enrichment layers of different deformation zones are different. For instance, the oil in the slope zone occurs mainly in the Permian Jiamuhe Formation $\left(\mathrm{P}_{1} \mathrm{j}\right)$ (Fig. 3), whereas the oil in the nappe pinch zone, faulted zone, and fault front zone occurs in the Triassic strata. Such distribution difference reflects the differences in the oil source and migration pathway in different parts of the region.

\subsection{Oil classification}

GC-MS analysis of the oil samples in the region indicates that the geochemical characteristics of the oil are similar on the whole, but the distribution characteristics of sterane and terpane are different, reflecting the difference in their sources. According to three parameters including tricyclic terpane $\mathrm{C}_{20}$ / $\mathrm{C}_{23}$ ratio, $\mathrm{C}_{24}$ tetracyclic terpane / $\mathrm{C}_{26}$ tricyclic terpane ratio, and gammacerane / $\mathrm{C}_{30}$ hopane ratio, the oil in the region was classified into two types named as type A and type B (Fig. 4).

The tricyclic terpane $C_{20} / C_{23}$ ratio of type $A$ oil is less than 1.0, and its $\mathrm{C}_{24}$ tetracyclic terpane / $\mathrm{C}_{26}$ tricyclic terpane ratio is less than 0.92 , suggesting that the original source material was algae (Volkman et al, 1989; Aquino Neto et al, 1989). The gammacerane / $C_{30}$ hopane ratio of type $A$ oil is greater than 0.29 , reflecting high water salinity (Moldowan et al, 1985; Fu et al, 1986) (Figs. 4(a)-4(d)). In addition, based on the relative content of regular sterane $\mathrm{C}_{29} \mathrm{~S}$ configuration and $\mathrm{R}$-configuration, the type $\mathrm{A}$ oil can be divided into two subtypes named as $A_{1}$ and $A_{2}$. The maturity of subtype $A_{1}$ oil is lower than that of subtype $A_{2}$.

The tricyclic terpane $\mathrm{C}_{20} / \mathrm{C}_{23}$ ratio of type $\mathrm{B}$ oil is greater than 1.0, and its $\mathrm{C}_{24}$ tetracyclic terpane / $\mathrm{C}_{26}$ tricyclic terpane ratio is greater than 0.92 , reflecting that algae was not the dominant source materials. The gammacerane / $\mathrm{C}_{30}$ hopane ratio of type $\mathrm{B}$ oil is lower than that of type $\mathrm{A}$ oil, and the water salinity in the parent material depositional environment of type B oil is lower than that of type A (Fig. 4(e)). From the distribution characteristics of regular sterane $\mathrm{C}_{29}$, it can be seen that the maturity of type $\mathrm{B}$ oil is approximate to that of subtype $A_{2}$ oil (Fig. 4(f)), and they are both of relatively high maturity.

Type A oil is distributed mainly in the Huwan area and in blocks V and VIII, and type B oil is concentrated in the northern part of block VIII and Baikouquan area (Fig. 5). The oil on the hanging wall of the overthrust belt and the fault front zone on the foot wall in the Karamay Oilfield is mainly subtype $A_{2}$. Subtype $A_{1}$ oil is distributed mainly in the 


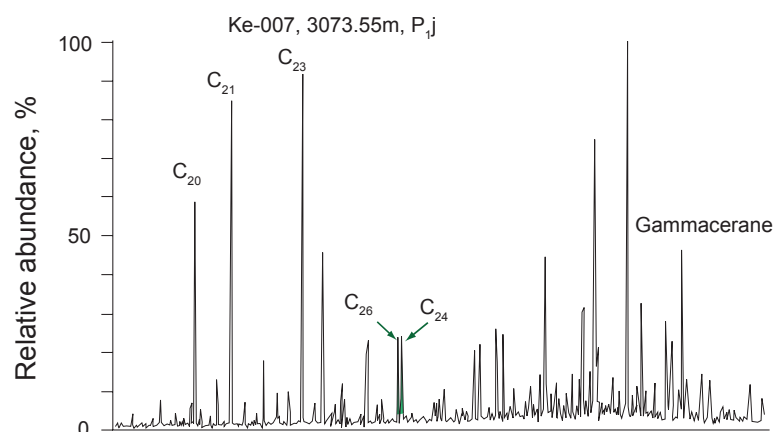

(a) Subtype $A_{1}$

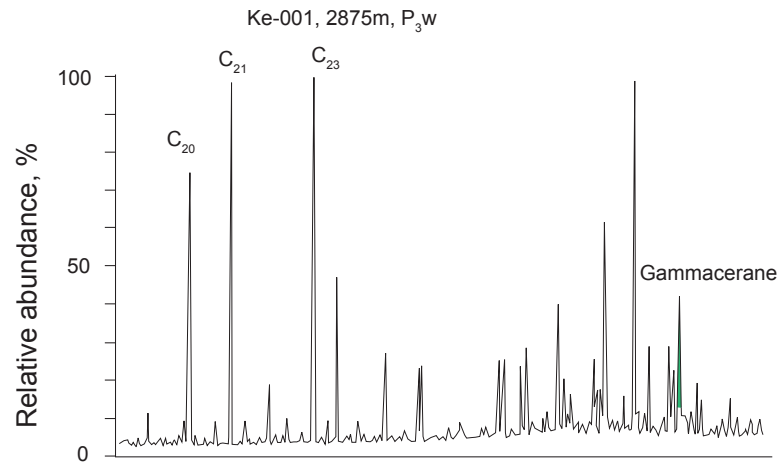

(c) Subtype $A_{2}$

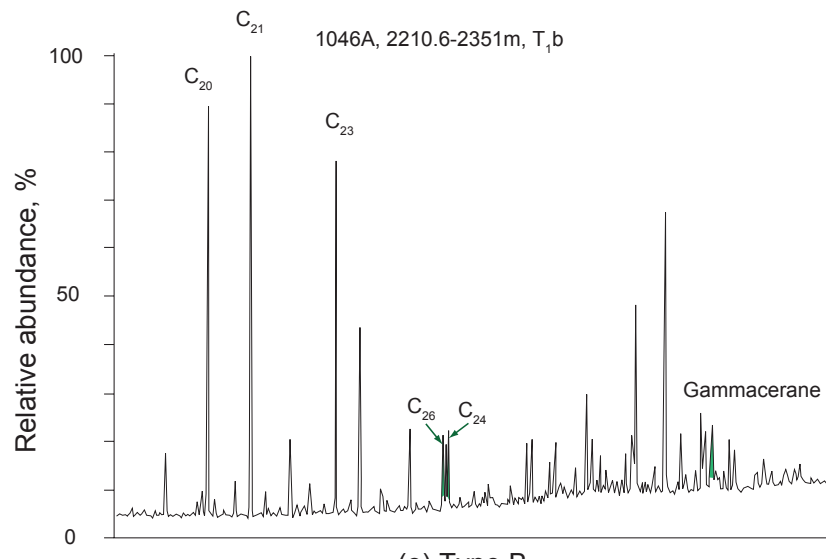

(e) Type B

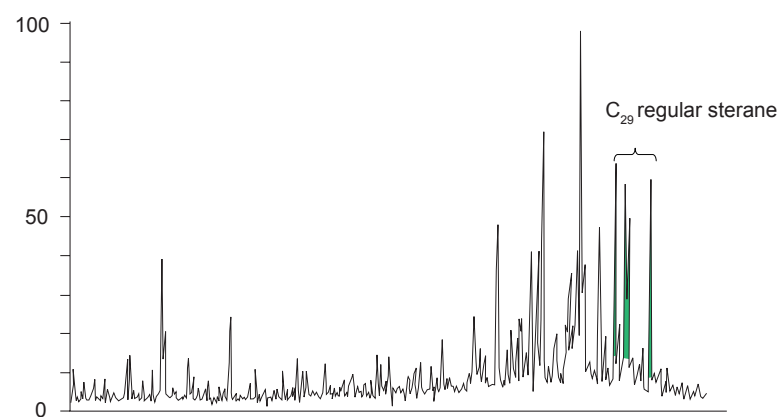

(b) Subtype A

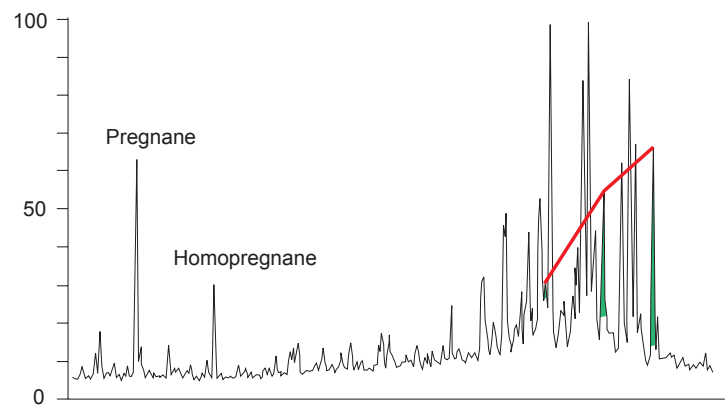

(d) Subtype A

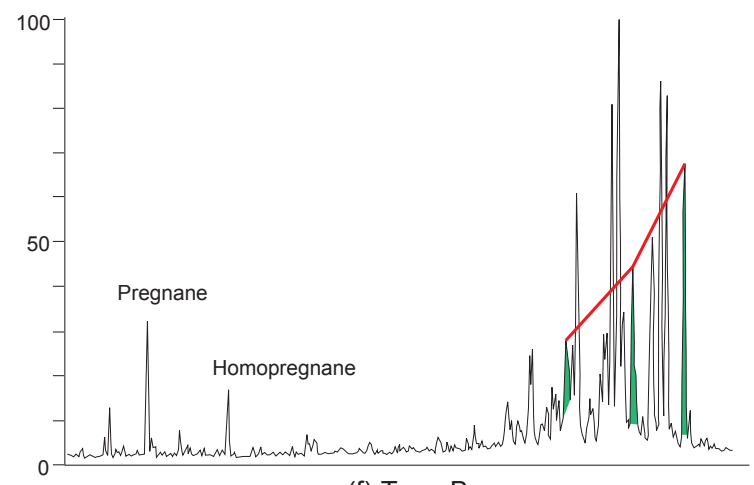

(f) Type B

Fig. 4 Terpane and sterane characteristics of different types of oil (left: terpane; right: sterane)

Permian strata in the blocks V and VIII. It can be seen that the oil type of the Baikouquan region is different from that of the Karamay Oilfield, and the oil type on the hanging wall and in the fault front zone is also different from that in the Permian of blocks $\mathrm{V}$ and VIII.

If the Fengcheng Formation of the Mahu Depression is the main source rock in the region, the type $\mathrm{A}_{2}$ oil of higher maturity shall be closer to the Mahu Depression than type $A_{1}$ oil of lower maturity, but this is not the case. The distribution of different types of oil in the region does not follow this rule. In blocks V and VIII on the footwall of the overthrust, the type $A_{2}$ oil of higher maturity is closer to the Mahu Depression than type $A_{1}$ oil of lower maturity, but the type $\mathrm{A}_{2}$ oil of higher maturity also exists in the Huwan area on the hanging wall and the fault front zone, which are even farther from the Mahu Depression. This indicates that the oil source in blocks V and VIII on the footwall of the overthrust is different from that in the Huwan area and the fault front zone. The oil in the downdip area in blocks V and VIII came from the Mahu Depression and the oil maturity decreased gradually from east to west, indicating oil migration from east to west. However, this maturity trend stopped before the fault front zone, and the oil in the fault front zone and on the hanging wall became high maturity oil again, so it may have a different source.

\section{Oil migration}

The diasterane / regular sterane ratio and $\mathrm{C}_{30}$ moretane $/ \mathrm{C}_{30}$ hopane ratio in oil are two important migration 


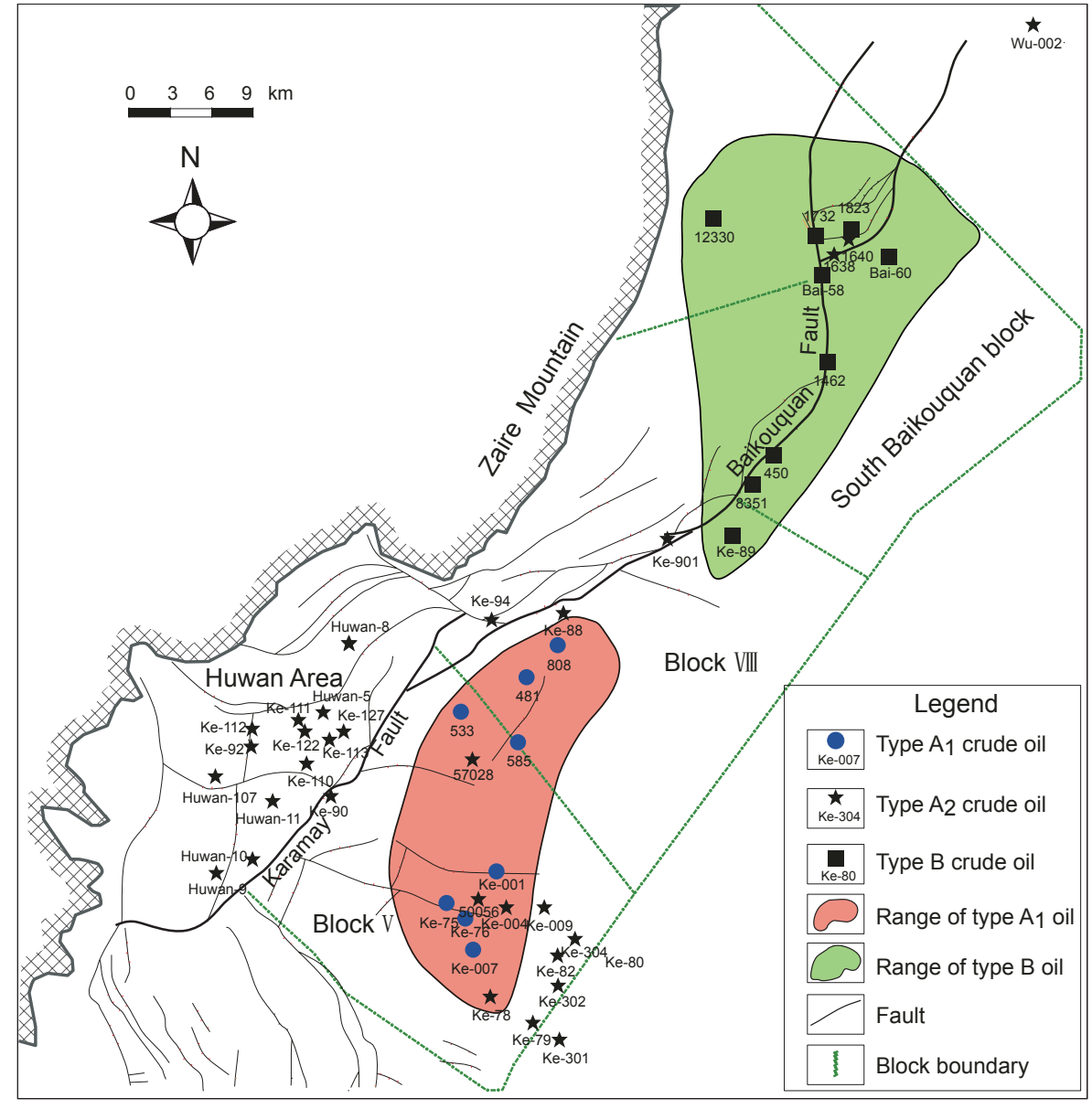

Fig. 5 Oil type distribution characteristics and migration direction

parameters. With increase of migration distance, the two parameters of the oil from the same source increase gradually, which can effectively indicate the oil migration direction.

The trend of diasterane / regular sterane and $\mathrm{C}_{30}$ moretane / $\mathrm{C}_{30}$ hopane ratios indicates that the oil migration direction in the Ke-Bai region is complex (Fig. 6). The diasterane / regular sterane ratio increases gradually from 0.21 to 0.94 and the $\mathrm{C}_{30}$ moretane / $\mathrm{C}_{30}$ hopane ratio increases from 0.16 to 0.26 in the direction from well $\mathrm{Ke}-80$ to well $\mathrm{Ke}-002$ in the southern part of block $\mathrm{V}$, suggesting that the oil migration direction in the area is from southeast to northwest. Similarly, this trend stops before the fault front zone, and the values above mentioned in the fault front zone decrease again, e.g., the diasterane / regular sterane and the $\mathrm{C}_{30}$ moretane / $\mathrm{C}_{30}$ hopane ratios of the oil sample from well Ke-90 near the fault are 0.20 and 0.18 , respectively. Then on the hanging wall of the fault, the values increase from east to west starting from the fault front zone, e.g., the diasterane / regular sterane and the $\mathrm{C}_{30}$ moretane / $\mathrm{C}_{30}$ hopane ratios increase from 0.20 and 0.18 at the well Ke-90 near the fault to 0.64 and 0.30 at the well Ke-107, respectively.

The lateral variations of migration parameters indicated different migration trends of oil between blocks V and VIII and the Huwan area. The diasterane / regular sterane ratio in blocks V and VIII gradually increased from southeast to northwest, indicating westward migration of oil. This trend was similar with that in oil type and maturity, indicating that the oil of blocks V and VIII came from the Mahu Depression. However, the diasterane / regular sterane ratio was low near the Ke-Bai overthrust belt and gradually increased towards the Huwan area, indicating another migration system. Therefore, it is considered that the oil in blocks $\mathrm{V}$ and VIII and the Huwan area came from different hydrocarbon kitchens.

In addition, the carbon isotope ratio of type A oil in the Huwan area is significantly heavier than that in blocks $\mathrm{V}$ and VIII (Fig. 7), showing that their source materials are different and also proving that there are other oil sources in the Huwan area.

\section{Oil source in the Karamay Oilfield}

The above analysis indicated that the majority of oil on the hanging wall, in the fault zone and fault front zone of the Ke-Bai overthrust belt in the Karamay Oilfield had a different source from the oil in the slope area in blocks V and VIII and the Baikouquan Oilfield which was believed to come from the Fengcheng Formation in the Mahu Depression. The interpretation of seismic data indicated that the Permian strata within the basin extends deeply below the overthrust nappe (Fig. 8), but it is difficult to determine accurately the horizons because of the poor quality of the seismic data below the nappe. It is therefore reasonable to believe that the Fengcheng 


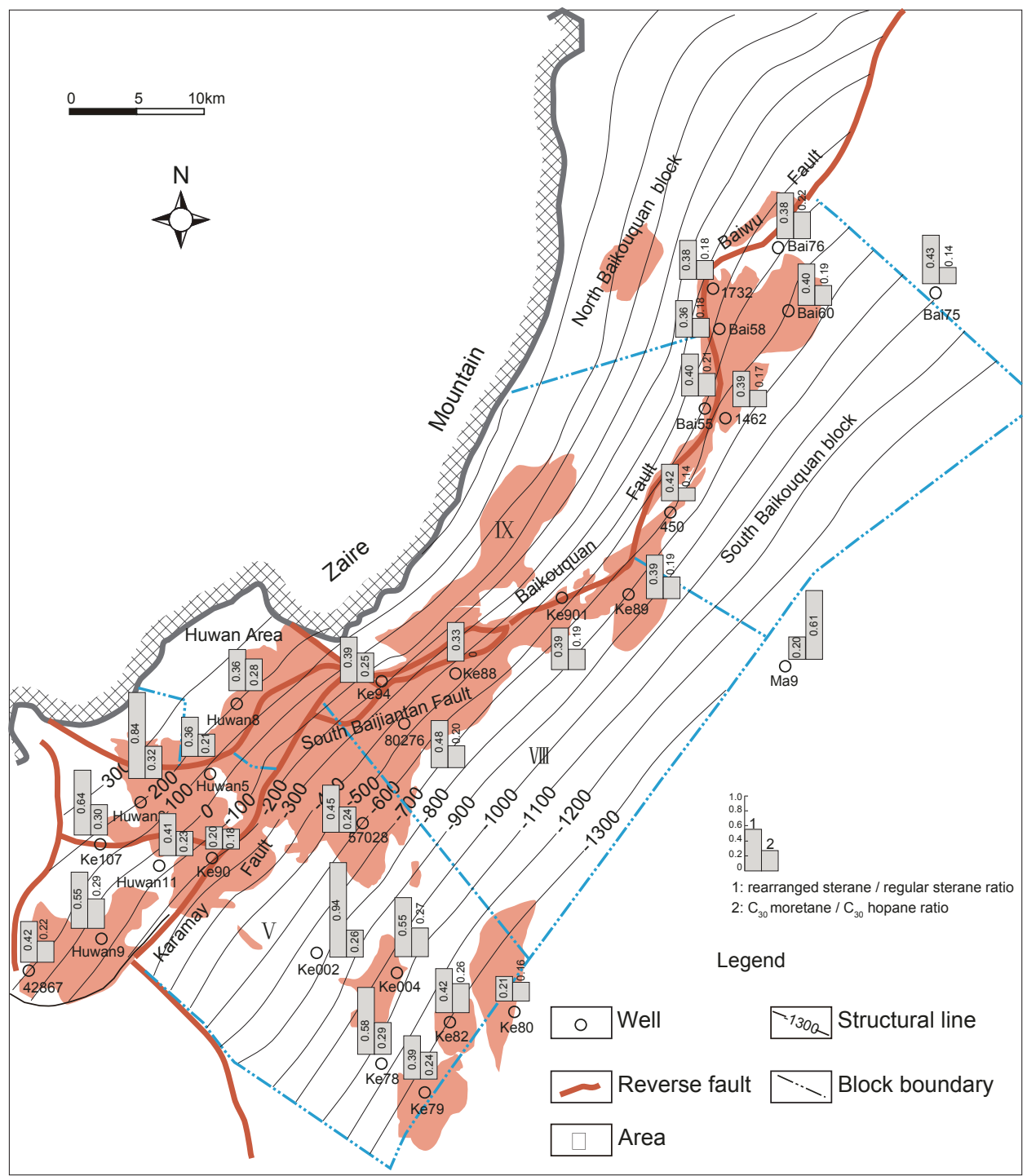

Fig. 6 Oil migration characteristics in the Ke-Bai region in the northwestern margin of the Junggar Basin

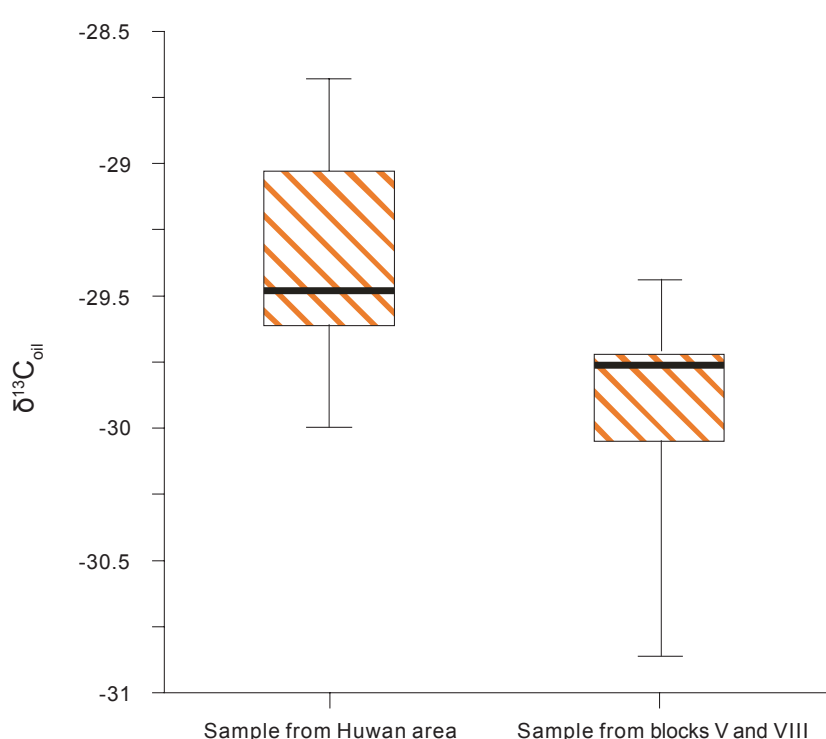

Fig. 7 Carbon isotope distribution characteristics of type A oil in the Ke-Bai region
Formation may extend below the nappe, and that this is the main source rock within the basin. As a result, the majority of oil in the Karamay Oilfield probably comes from the source rocks of the Fengcheng Formation below the nappe that have not yet been recognized. This can reasonably explain why there are differences in maturity, migration direction, and carbon isotope of the same type of oil between the Huwan area and blocks V and VIII.

Based on the above analysis, the oil migration model in the Ke-Bai region can be established as follows. Oil generated by the source rocks of the Fengcheng Formation in the Mahu Depression migrated mainly along the unconformities at the top of the Jiamuhe Formation from east to west, resulting in Permian hydrocarbon accumulation in the slope area in blocks V and VIII and the Baikouquan Oilfield. The source rocks of the Fengcheng Formation below the overthrust nappe were the main source of the Karamay Oilfield, and the oil generated here migrated upward along overthrust faults and accumulated in the Triassic and Jurassic strata to form reservoirs in the Huwan area, fault zone, and fault front zone of the Ke-Bai overthrust belt in the Karamay Oilfield. 


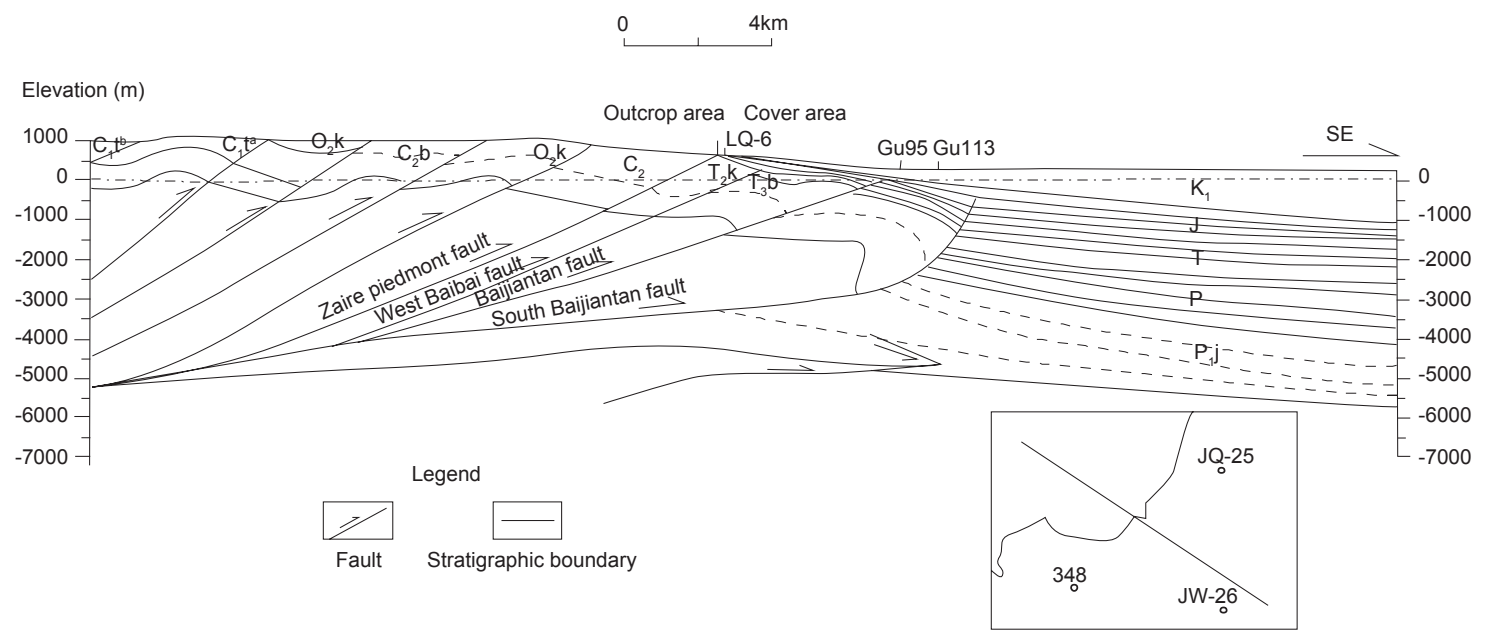

Fig. 8 KB200601 seismic interpretation profile in the Ke-Bai region (from the achievements of the Technology Development Project in Xinjiang Oilfield, 2008)

\section{Conclusions and discussion}

The analysis of oil type and hydrocarbon migration direction in this paper indicates that the majority of oil in the overthrust belt in the northwestern margin of the Junggar Basin might come from a new oil source kitchen below the overthrust belt. This new viewpoint could reasonably explain the uneven distribution of oil around the Mahu Depression and the changes in oil types and their geochemical characteristics. In addition, this viewpoint could provide a theoretical basis for opening up a new hydrocarbon exploration field in Carboniferous strata in the region. In the past exploration of the Carboniferous, the hanging wall of the Ke-Bai overthrust belt was focused on the weathering crust based on the traditional view that oil came from the Mahu Depression along the unconformity. If oil came from a source kitchen below the overthrust nappe, the upward migrating oil could have migrated along faults inside the Carboniferous and then accumulated in the Triassic and Jurassic to form the Karamay Oilfield, so a reservoir inside the Carboniferous would accumulate oil as the fault-induced fractures might improve the reservoir quality. So importance should be further attached to the exploration in Carboniferous strata on the hanging wall.

\section{References}

Alsharhan A S. Depositional environment, reservoir units evaluation, and hydrocarbon habitat of Shuaiba Formation, Lower Cretaceous, Abu Dhabi, United Arab Emirates. AAPG Bulletin. 1985. 69(6): 899-912

Ameen M S. Alpine geowarpings in the Zagros-Taurus range: influence on hydrocarbon generation, migration and accumulation. Journal of Petroleum Geology. 1991. 14(4): 417-428

Aquino Neto F R, Triguis J, Azevedo D A, et al. Organic geochemistry of geographically unrelated Tasmanites. The 14th International Meeting on Organic Geochemistry. Paris, September 18-22, 1989. Abstract No.169

Dahl J, Moldowan J M, Summons R E, et al. Extended 3 $\beta$-alkyl steranes and 3-alkyl triaromatic steroids in crude oils and rock extracts. Geochimica et Cosmochimica Acta. 1995. 59(18): 3717-3729
Fu J M, Sheng G Y, Peng P A, et al. Peculiarities of salt lake sediments as potential source rocks in China. Organic Geochemistry. 1986. 10(1-3): 119-126

Guan S W, Li B L, Hou L H, et al. New hydrocarbon exploration areas in footwall covered structures in northwestern margin of Junggar Basin. Petroleum Exploration and Development. 2008. 35(1): 17-22 (in Chinese)

Horsfield B, Curry D J, Bohacs K, et al. Organic geochemistry of freshwater and alkaline lacustrine sediments in the Green River Formation of the Washakie Basin, Wyoming, USA. Organic Geochemistry. 1994. 22(3-5): 415-440

Jia C Z, Zhou X Y, Wang Z M, et al. Discovery of Kela-2 Gas Field and exploration technology. China Petroleum Exploration. 2002. 7(1): 7988 (in Chinese)

Macqueen R W and Leckie D A. Foreland Basins and Fold Belts. AAPG Memoir 55. 1997

McClay K R. Thrust Tectonics and Hydrocarbon Systems. AAPG Memoir 82. 2004

Moldowan J M, Seifert W K and Gallegos E J. Relationship between petroleum composition and depositional environment of petroleum source rocks. AAPG Bulletin. 1985. 69(8): 1255-1268

Peters K E, Moldowan J M and Sundararaman P. Effects of hydrous pyrolysis on biomarker thermal maturity parameters: Monterey phosphatic and siliceous members. Organic Geochemistry. 1990. 15(3): 249-265

Qiu Z J and Gong Z S. China Petroleum Exploration. Beijing: Petroleum Industry Press. 1999. 78-89 (in Chinese)

Summons R E, Thomas J, Maxwell J R, et al. Secular and environmental constraints on the occurrence of dinosterane in sediments. Geochimica et Cosmochimica Acta. 1992. 56(6): 2437-2444

Thomas J B, Marshall J, Mann A L, et al. Dinosteranes (4, 23, 24trimethylsteranes) and other biological markers in dinoflagellaterich marine sediments of Rhaetian age. Organic Geochemistry. 1993. 20(1): 91-104

Volkman J K, Banks M R, Denwer K, et al. Biomarker composition and depositional setting Tasmanite oil shale from northern Tasmania, Australia. The 14th International Meeting on Organic Geochemistry. Paris, September 18-22, 1989. Abstract No.168

Wang X L and Kang S F. Analysis of crude oil origin in hinterland and slope of northwestern margin, Junggar Basin. Xinjiang Petroleum Geology. 1999. 20(2): 108-112 (in Chinese)

Wilson H H. Hydrocarbon habitat in main producing areas, Saudi 
Arabia: discussion. AAPG Bulletin. 1982. 66(12): 2688-2691

Wolff G A, Lamb N A and Maxwell J R. The origin and fate of 4-methyl steroid hydrocarbons. I: Diagenesis of 4-methyl sterenes. Geochimica et Cosmochimica Acta. 1986. 50(3): 335-342

Wu K Y, Zha M and Liu G D. The unconformity surface in the Permian of Junggar Basin and the characteristics of oil-gas migration and accumulation. Petroleum Exploration and Development. 2002. 29(2): 53-57 (in Chinese)

Young A, Monaghan P H and Schweisberger R T. Calculation of ages of hydrocarbons in oils - physical chemistry applied to petroleum geochemistry. AAPG Bulletin. 1977. 61(4): 573-600

Zhai G M. Petroleum Geology in China (Vol. 13). Beijing: Petroleum Industry Press. 1989. 1-33 (in Chinese)

Zhang L P, Wang S J and Qu H. Geochemistry of crude oil and oil- source analysis of Junggar Basin. China Petroleum Exploration. 2000. 5(3): 30-35 (in Chinese)

Zhang Y Q and Zhang N F. Oil/gas enrichment of a large superimposed basin in Junggar Basin. China Petroleum Exploration. 2006. 11(1): 59-64 (in Chinese)

Zou H Y, Hao F, Zhang B Q, et al. Control of main expelling pathway for overpressure fluid on gas migration and accumulation in Kelasu overthrust belt of Kuqa Depression. Acta Petrolei Sinica. 2005. 26(2): 11-14 (in Chinese)

Zou H Y, Wang H J, Hao F, et al. Rapid hydrocarbon accumulation mechanism in later period in Kelasu thrust belt in Kuqa Depression. Science in China (Series D). 2007. 50(8): 1161-1170 (in Chinese)

(Edited by Hao Jie) 